\title{
Model Pembelajaran Langsung : Solusi Masalah Keterbatasan Waktu Pada Pembelajaran IPS
}

\author{
Eri Susanto \\ Pascasarjana UIN Sunan Kalijaga Yogyakarta \\ eriisusanto21@gmail.com
}

\begin{abstract}
Abstrak: Riset ini dilaksanakan dimaksudkan supaya menyelesaikan kesulitan yang dihadapi oleh guru kelas dengan menggunakan model pembelajaran langsung, yaitu ketika guru memiliki keterbatasan waktu tetapi materi yang diajarkan luas seperti pada mata pelajaran IPS materi kerajaan Hindu-Budha dan Islam. Model pembelajaran langsung ialah model pembelajaran yang berorientasi kepada teacher centre. Penelitian ini merupakan hasil dari kajian pustaka dengan cara riset kepustakaan. Hasil penelitian ini mengungkapkan langkah-langkah model pembelajaran langsung pada mata pelajaran IPS yaitu; pertama, guru menyampaikan tujuan pembelajaran, estimasi waktu serta menyiapkan siswa ketika
\end{abstract}

\begin{tabular}{l}
\hline Tersedia Online di \\
\hline http://journal.unublitar.ac.id/pendidikan/i \\
\hline ndex.php/Riset_Konseptual \\
\hline Sejarah Artikel \\
\hline Diterima pada : 28-11-2020 \\
Disetuji pada : 30-01-2021 \\
Dipublikasikan pada : 31-01-2021
\end{tabular}

Kata Kunci:

Model pembelajaran langsung, Mata pelajaran IPS, Keterbatasan waktu guru.

DOI:

http://doi.org/10.28926/riset_konseptual.v5i1.311 pembelajaran akan dimulai; kedua, guru menyampaikan informasi/materi pembelajaran IPS yaitu tentang kerajaan Hindu-Budha dan Islam, bisa menggunakan metode ceramah, demontrasi, atau kerja kelompok; ketiga, untuk mengetahui berkaitan dengan pemahaman siswa, guru melemparkan pertanyaan kepada siswa dengan harapan siswa sudah paham dengan materi.; dan keempat adalah pemberian tugas kepada siswa dengan tujuan siswa dapat menuangkan informasi yang di dapat selama pembelajaran.

\section{PENDAHULUAN}

Pendidikan merupakan kebutuhan hidup setiap manusia. Pemerintah wajib memastikan dan menfasilitasi semua warga Negara dapat menikmati pendidikan. Dalam UU No. 20 tahun 2003 tentang Sisdiknas, Pemerintah wajib mengalokasikan anggaran sebanyak $20 \%$ dari APBN untuk kebutuhan pendidikan. Banyak fasilitas pendidikan dan tenaga guru telah disediakan oleh pemerintah.

Guru diharapkan mempunyai kompetensi yang unggul diantaranya; kompetensi pedagogik, kompetensi kepribadian, kompetensi sosial dan kompetensi profesional. Karena pendidik mempunyai tugas tambahan yang sangat banyak, maka ada kompetensi guru yang kurang terpenuhi semisal kompetensi professional utamanya dalam hal manajemen waktu.

Kemampuan manajemen waktu sangat penting dimiliki seorang guru. Tanpa manajemen waktu guru, akan sering menunda-nunda tugasnya ataupun tidak memanfaatkan waktu dengan baik. Hal ini tentu akan berakibat dengan seringnya mengalami keterlabatan dalam menyelesaikan tugasnya dan lebih parah lagi yaitu akan gagal menyelesaikan tugas. Dalam ilmu psikologi perilaku menunda-nunda dan tidak memanfaatkan waktu dengan baik ini disebut Prokatinisasi. Prokatinisasi menurut Sandra ialah, sikap menangguhkan mengerjakan sesuatu, menunda-nunda sampai suatu waktu yang akan datang.(Sandra, 2013)

Prokatinisasi bagi seorang guru merupakan sikap yang harusnya tidak terdapat pada guru profesional. Guru profesional akan memanfaatkan waktu yang ia miliki untuk mempersiapkan pembelajaran untuk esok hari. Mempersiapkan pembelajaran penting dilakukan oleh guru supaya pembelajaran dapat diterima dengan baik dan bermakna oleh siswa. Apalagi tugas guru tidak hanya mengajar saja tetepi guru juga memiliki tugas tambahan disamping mengajar, semisal tugas administrasi maupun tugas tambahan lain yang dibebankan sekolah kepada guru. 
Hal ini sejalan dengan hasil penelitian bahwa guru memiliki tugas tambahan yang sangat banyak.(Retnawati, 2015) Sehingga mengakibatkan banyak materi yang sekiranya diajarkan menjadi tidak diajarkan dikarenakan keterbatasan waktu.(Purwianingsih dkk., 2009)

Keterbatasan waktu perlu diatasi dengan cara menajemen waktu bila tidak memanage waktu dengan baik maka guru tidak dapat mengajarkan materi-materi yang diajarkan secara tuntas misalkan saja pada mata pelajaran IPS. Tentu sangat akan merugikan siswa jika materi IPS tidak tuntas dan mengakibatkan nilai siswa menjadi buruk.

Berdasarkan studi pendahuluan yang dilakukan penulis kepada ibu Evi Wulandari S.Pd. guru kelas 4 di SD Mangir Lor. Beliau kesulitan dalam mengajarkan di tema terakhir yaitu materi kerajaan Hindu, Budha dan Islam dikarenakan keterbatasan waktu yang sudah dekat dengan UAS sehingga materi tidak tersampaikan secara maksimal dan mengakibatkan nilai siswa saat ujian akhir semester menjadi buruk pada mata pelajaran IPS.

Menurut Mulyaning Tyas, materi ajar yang disampaikan tidak tuntas maka berakibat hasil belajar yang rendah. Kondisi ini berdasar kenyataan dengan banyaknya siswa yang belum tuntas dengan KKM yang ditentukan.(Mulyaning Tyas, 2016) Pada penelitian lain menyebutkan hasil belajar yang rendah disebabkan dari aspek internal dan eksternal dari diri siswa. Salah satu factor eksternalnya yaitu guru menyampaikan materi tidak tuntas dikarenakan keterbatasan waktu. Jika tidak segera ditangani dan ditemukan solusinya maka siswa akan mengalami kesulitan belajar yang berakibat rendahnya prestasi belajar siswa.(Khaira, 2017)

Salah satu solusi mengatasi kesulitan belajar yang dapat dilakukan guru kepada siswanya ialah melalui penerapan model pembelajaran. Menurut Sundawan, model pembelajaran ialah tehnik dan kaidah yang dapat diaplikasikan oleh guru agar tercapai tujuan tertentu dalam pembelajaran. Guru perlu menetapkan model pembelajaran yang cocok dan sinkron dengan meteri yang akan diajarkan, supaya materi yang diajarkan bisa diterima dan dimengerti oleh siswa.(Sundawan, 2016) Bermacam model pembelajaran yang bias dimanfaatkan guru berkaitan mengatasi keterbatasan waktu dalam pembelajaran, terkhusus dalam hal IPS diantaranya yaitu model pembelajaran langsung.

Panjaitan mengemukakan bahwa model pembelajaran langsung ialah model pembelajaran yang berorientasi teacher centre .(Panjaitan, 2017) Sering kita bahwa pembelajaran langsung dan metode ceramah itu sama, padahal itu dua hal yang berbeda. Metode caramah adalah irisan dari pembelajaran langsung dan bentuk penyampaian informasi secara lisan ke siswa.(Widyantini, 2012)

Pembelajaran langsung memerlukan persiapan yang mendetail guna pembelajaran berjalan lancar. Pembelajaran langsung memang bersifat teacher centris, tetapi juga harus mengakomodir keterlibatan siswa dalam pembelajaran. Sehingga, perlu diciptakan lingkungan yang mampu mendukung proses ceramah dan resitasi ( pengecekan pemahaman melalui Tanya jawab).(Panjaitan, 2017)

Sebab itu peneliti terdorong untuk melakukan riset ini dengan tujuan untuk menyelesaikan ksulitan yang dihadapi oleh guru kelas saat melakukan pembelajaran tetapi tidak tuntas dikarenakan keterbatasan waktu. Dengan model pembelajaran langsung, diharapkan guru mampu menyampaikan materi secara tuntas dan efisien walaupun dengan waktu yang terbatas khususnya dalam pembelajaran IPS. 
Riset ini menggunakan metode kualitatif dengan studi literature dari beberapa sumber baik media cetak dan elektronik, serta buku dan jurnal elektronik. Pencarian jurnal dilakukan melalui Google Cendekia. Selann itu juga melakukanobservasi ke lapangan yang akan dijadikan data sekunder/pendukung. Berdasarkan hasil pencarian data yang diperoleh dan dipilih yang memenuhi kriteria. Analisis tinjauan literature termasuk penghimpunan data, reduksi data, dan penarikan kesimpulan.

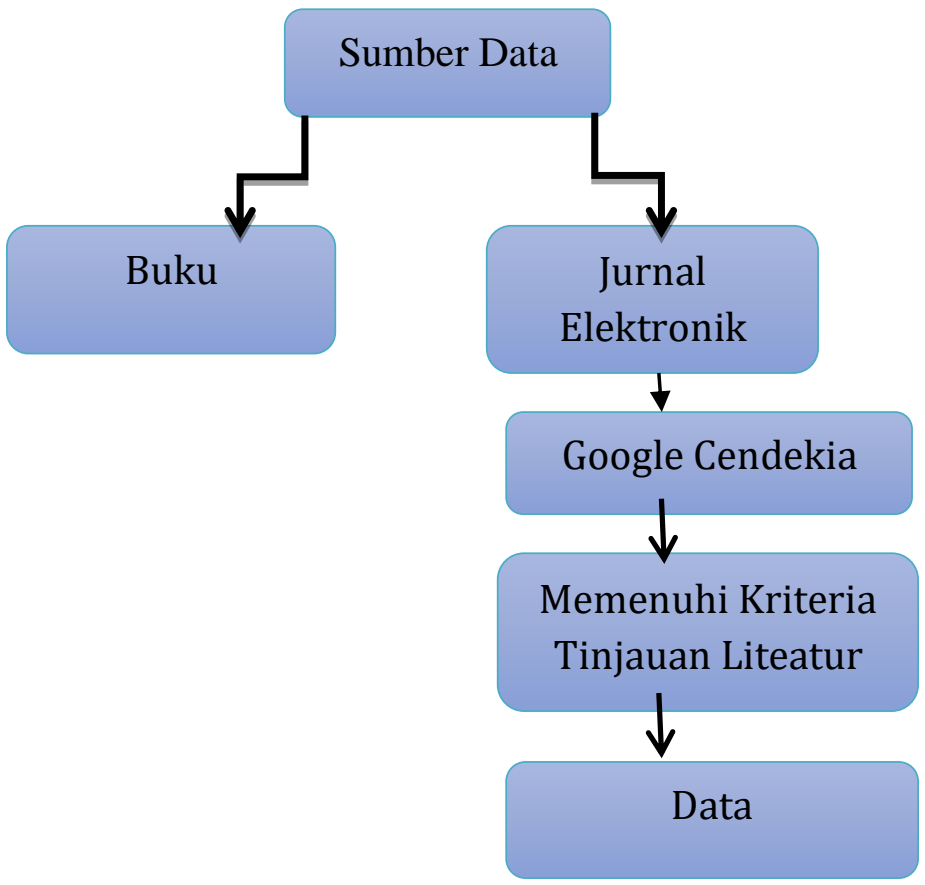

Bagan 1. Bagan metodologi penelitian

HASIL dan PEMBAHASAN

Mata pelajaran IPS ialah bentuk salah satu disiplin ilmu yang ada pada tingkatan SD. IPS mempelajari tentang pembelajaran sosial dan humaniora serta seluruh pola interaksi manusia yang dijabarkan secara keilmuan dalam rangka membagikan pengetahuan kepada siswa khususnya di jenjang SD. Selain itu IPS juga mengkaji bagian-bagian dari disiplin ilmu sosial seperti; ilmu geografi, sejarah, ekonomi, antropologi, sosiologi, politik dan psikologi.(Syahbani, 2018)

IPS memiliki ruang lingkup yang meliputi perilaku social manusia, ekonomi, dan budaya di masyarakat. Perilaku manusia dan masyarakat merupakan objek utama dalam IPS. Berbagai aspek perilaku social terkait dengan ruang tempat tinggalnya, hubungan social kemasyarakatan, ekonomi, sejarah, kebudayaan, kejiwaan, geografis, politik dan apapun obyeknya yang berkaitan dengan hubungan manusia dengan masyarakat.(Wuryani, 2019)

Ruang lingkup materi pembelajaran IPS yang sangat luas. Tentunya supaya mampu mengertii dan memahami materi IPS secara efektif dibutuhkan beberapa factor diantaranya ; adanya interaktif yang baik antara siswa dan guru, guru menguasai materi IPS dan yang terakhir memiliki waktu yang cukup untuk pembelajaran IPS.(Maemunah, 2013) Tetapi terkadang guru tidak mempunyai waktu yang memadai untuk melaksanakan pembelajaran dikarenakan guru memiliki beban tambahan yang banyak.

Menurut Ridhowati, guru memiliki factor-faktor penghambat dalam melaksanakan pembelajaran dengan baik, salah satunya guru memiliki keterbatasan waktu dalam mengajar.(Ridhowati, 2015) Untuk mengatasi keterbatasan waktu yang berakibat dengan tidak tuntasnya materi pembelajaran. Guru seringkali hanya menjelaskan 
sekali lalu memberikan tugas kepada siswa pada saat itu juga.(AEDI, 2008) Sehingga berakibat siswa kurang paham akan materi.

Dibutuhkan model pembelajaran yang tepat guna mengatasi keterbatasan waktu guru dalam mengajarkan materi yang tergolong luas seperti IPS. Model pembelajaran langsung merupakan salah satu alternatif yang dapat digunakan guru dalam situasi waktu yang mepet dan materi yang diajarkan luas.

Model pembelajaran langsung dalam Pritandari, ialah model pembelajaran yang didesain secara ekslusif supaya dapat mengakomodir jalannya pembelajaran siswa yang berhubungan pada pemahaman deklaratif dan pemahaman procedural. Pemahaman deklaratif menurut ahli adalah pemahaman yang dapat diekspresikan dengan kata-kata, sedang procedural merupakan pemahaman tentang bagaimana melakukan sesuatu.(Pritandhari, 2017) Selain itu menurut Killen, pembelajaran langsung juga merupakan tekhnik pembelajaran ekspositori yang memindahkan pengetahuan dari guru ke siswa yang melibatkan seluruh kelas.(Yulianto, 2016)

Terdapat beberapa penelitian sebelumnya yang memfokuskan meneliti tentang model pembelajaran langsung sebagai solusi alternative keterbatasan waktu dan memiliki materi yang luas, yaitu penelitian dari Hamka menyebutkan model pembelajaran langsung sangat efektif diterapkan pada meteri yang luas dan terstrukur yaitu materi system gerak. Selain itu model pembelajaran langsung juga memiliki keunggulan yaitu guru bisa mengatur rangkaian dan besarnya materi, maka bias mudah melihat sejauh mana siswa memahami materi, selain itu juga guru dapat mengontrol waktu yang dibutuhkan dalam pembelajaran, pembelajaran dapat dipercepat maupun diperlambat oleh guru.(Hamka L \& Nur Arsyad, 2015)

Pada penelitian lain yaitu oleh Ni'mah berpendapat bahwa pembelajaran langsung dapat diterapkan pada keterampilan pengambilan keputusan, selain itu pembelajaran langsung yang digunakan guru dalam pembelajaran ke siswa juga harus dapat mengatur waktu seefisien mungkin demi tercapainya tujuan pembelajaran.(Ni'mah, 2013)

Harahap mengemukakan dalam penelitiannya bahwa, pembelajaran langsung bisa mendorong peningkatan output belajar siswa pada bab kegiatan kepengurusan jenazah. Guru memegang peran penting yaitu sebagai penyampai materi dan pengontrol pembelajaran sehingga dapat mengatur waktu. Sedangkan siswa berperan mengamati, mengingat dan meniru apa yang disampaikan gurunya.(Harahap dkk., 2017)

Dari beberapa penelitian sebelumnya dapat diambil informasi bahwa guru sebagai pusat pembelajaran dan sebagi pengontrol pembelajaran. Sehingga dapat mengatur waktu yang dibutuhkan selama pembelajaran langsung terutama jika materi yang akan diajarkan luas seperti pada pembelajaran IPS tentang kerajaan HinduBudha dan Islam. Berikut langkah-langkah pembelajaran langsung dalam pembelajaran IPS yang perlu guru ketahui; pertama, guru menyampaikan tujuan pembelajaran, estimasi waktu serta menyiapkan siswa ketika pembelajaran akan dimulai; kedua, guru menyampaikan informasi/materi pembelajaran IPS yaitu tentang kerajaan Hindu-Budha dan Islam, bisa menggunakan metode ceramah, demontrasi, atau kerja kelompok; ketiga, untuk mengecek pemahaman siswa, guru melemparkan pertanyaan kepada siswa dengan harapan siswa sudah paham dengan materi.; dan keempat adalah pemberian tugas kepada siswa dengan tujuan siswa dapat menuangkan informasi yang di dapat selama pembelajaran.

Setelah mengetahui langkah-langkah pembelajaran langsung terutama pada IPS materi kerajaan Hindu-Budha dan Islam yang materinya luas, diharapkan guru yang memiliki keterbatasan waktu dalam penyampaian pada meteri ini, dapat terbantu menemukan solusi dan melakukan pembelajaran dengan lebih baik lagi. 


\section{KESIMPULAN}

Berdasar temuan penelitian dan pembahasan diatas bisa ditarik kesimpulan, model pembelajaran langsung dapat dijadikan alternative solusi guru ketika memiliki keterbatasan waktu dan materi yang akan diajarkan luas seperti pembelajaran IPS materi kerajaan Hindu-Budha dan Islam dengan memperhatikkan langkah-langkah model pembelajaran langsung dalaam pembelajaran IPS..

\section{DAFTAR RUJUKAN}

Aedi, N. (2008). Pemantauan Standar Nasional Dalam Pengajaran. Direktorat Jenderal Peningkatan Mutu Pendidik Dan Tenaga Kependidikan Departemen Pendidikan Nasional.

Hamka L, \& Nur Arsyad, M. (2015). Keefektifan Penerapan Model Pembelajaran Langsung Pada Materi Sistem Gerak Di Sma Negeri 1 Donri-Donri. Jurnal Bionature, 16(1), 58-64.

Harahap, M. A., Sinaga, A. I., \& Halimah, S. (2017). Penerapan Strategi Pembelajaran Langsung Dengan Metode Drill Untuk Meningkatkan Aktivitas Belajar Dan Keterampilan Pelaksanaan Ibadah Pokok Bahasan Pengurusan Janazah Di Mts Al-Ma'shum Rantauprapat Labuhanbatu. Edu Riligia, 1(3), 15.

Khaira, S. (2017). Masalah -Masalah Dalam Belajar Dann Cara Mengatasinya [Phd Thesis]. Universitas Samudra Langsa.

Maemunah, M. (2013). Penggunaan Paired Story Telling Untuk Peningkatan Pembelajaran Ips Tentang Proklamasi Dan Perjuangan Mempertahankan Kemerdekaan Indonesisa Siswa Kelas V Sd. Kalam Cendekia Pgsd Kebumen, 5(3).

Ni'mah, R. F. (2013). Model Pembelajaran Langsung Untuk Meningkatkan Keterampilan Pengambilan Keputusan Siswa Sekolah Dasar. Jpgsd, 02, 13.

Panjaitan, D. J. (2017). Meningkatkan Hasil Belajar Siswa Dengan Metode Pembelajaran Langsung. Jurnal Mathematic Paedagogic, 1(1), 83-90.

Pritandhari, M. P. (2017). Implementasi Model Pembelajaran Direct Instruction Untuk Meningkatkan Kemampuan Berpikir Kreatif Mahasiswa. Promosi (Jurnal Pendidikan Ekonomi), 5(1). Https://Doi.Org/10.24127/Ja.V5i1.845

Purwianingsih, W., Rustaman, N. Y., \& Redjeki, S. (2009). Identifikasi Kesulitan Pembelajaran Bioteknologi Pada Guru Slta Se Jawa Barat. Seminar Nasional: Inovasi Biologi Dan Pendidikan Biologi Dalam Pengembangan Sumber Daya Manusia.

Retnawati, H. (2015). Hambatan Guru Matematika Sekolah Menengah Pertama Dalam Menerapkan Kurikulum Baru. Jurnal Cakrawala Pendidikan, 34(3).

Sandra, K. I. (2013). Manajemen Waktu, Efikasi-Diri Dan Prokrastinasi. Persona: Jurnal Psikologi Indonesia, 2(3).

Sundawan, M. D. (2016). Perbedaan Model Pembelajaran Konstruktivisme Dan Model Pembelajaran Langsung. Logika Jurnal IImiah Lemlit Unswagati Cirebon, 16(1).

Widyantini, T. (2012). Penerapan Model Pembelajaran Langsung Dalam Mata Pelajaran Matematika Smp/Mts. Pusat Pengembangan Dan Pemberdayaan Pendidik Dan Tenaga Kependidikan (Pppptk) Matematika.

Wuryani, E. (2019). Metode Literasi Dalam Pembelajaran Ips Materi Kerajaan-Kerajaan Hindu-Buddha Di Indonesia Pada Siswa Kelas Viib Smp Kristen Satya Wacana Salatiga.

Mulyaning Tyas, N. (2016). Analisis Faktor Penyebab Kesulitan Belajar Matematika Kelas Iv Sekolah Dasar Negeri Di Kecamatan Ungaran Barat Kabupaten Semarang [Phd Thesis]. Universitas Negeri Semarang.

Ridhowati, B. (2015). Faktor-Faktor Yang Menghambat Guru Dalam Melaksanakan Pembelajaran Akuntansi Dengan Pendekatan Kontekstual Pada Smk Negeri Bisnis Dan Manajemen Di Kabupaten Sleman Tahun Ajaran 2014/2015faktorFaktor Yang Menghambat Guru Dalam Melaksanakan Pembelajaran Akuntansi Dengan Pendekatan Kontekstual Pada Smk Negeri Bisnis Dan Manajemen Di 
Kabupaten Sleman Tahun Ajaran 2014/2015 [Phd Thesis]. Universitas Negeri Yogyakarta.

Syahbani, N. (2018). Peningakatan Hasil Belajar Ips Meteri Perjuangan Mempertahankan Kemerdekaan Indonesia Menggunakan Metode Story Telling Dan Media Audio Visual Gerak Pada Siswakelas V Semester li Mi Tarbiyatul Aulad Jombor Tuntang Kabupaten Semarang Tahun Pelajaran 2017/2018 [Phd Thesis]. lain Salatiga.

Yulianto, R. (2016). Penerapan Model Pembelajaran Langsung (Direct Instruction) Pada Pembelajaran Fisika Siswa Kelas Vii Smp Negeri 6 Lubuklinggau Tahun Pelajaran 2015/2016 [Phd Thesis]. Stkip-Pgri Lubuklinggau. 